\title{
Analysis of Support Systems and Excavation Methods Based on Rock Mass Quality in the Intake Tunnel of the Jlantah Dam
}

\author{
Doni Apriadi Putera ${ }^{1 *}$, Heru Hendrayana ${ }^{1}$, and Hendy Setiawan ${ }^{1}$ \\ ${ }^{1}$ Geological Engineering Departement, Engineering Faculty, Gadjah Mada University, Sleman, Yogyakarta, Indonesia
}

\begin{abstract}
Research on the classification of rock mass quality in the intake tunnel Jlantah dam has not been carried out in detail because the research focuses on the location of the main dam so that empirical excavation methods and support systems have not been carried out. The rock mass quality will be used as a parameter in determining the excavation method and tunnel support system that will be used in the Jlantah Dam intake tunnel. The investigation was carried out through engineering geological mapping, core drill evaluation, and supported by laboratory test data based on the Rock Mass Rating (RMR) and Q-system rock mass classification. The rock mass at the research location based on the RMR classification is in class IV (poor rock). Based on the Q-system method, a very poor rock class is obtained. Based on the analysis of the RMR and Q-system methods, the suitable support system for engineering geological conditions such as the intake tunnel of the Jlantah Dam is shotcrete $10 \mathrm{~cm}$ thick, steel set with a distance of $1.5 \mathrm{~m}$ and rockbolt length of $1.6 \mathrm{~m}$ with a distance of $1.5 \mathrm{~m}$. The proper excavation method for the tunnel intake is top heading and bench.
\end{abstract}

\section{Introduction}

The research location is at the Jlantah Dam construction site. Administratively, this dam is located in Tlobo Village, Jatiyoso District, Karanganyar Regency, Central Java Province (fig 1). The Jlantah Dam will produce raw water of 150 liters / second with a total storage capacity of 10.97 million $\mathrm{m} 3$, and this dam is also used as a Micro Hydro Power Plant (PLTMH) of 0.625 MW [6].

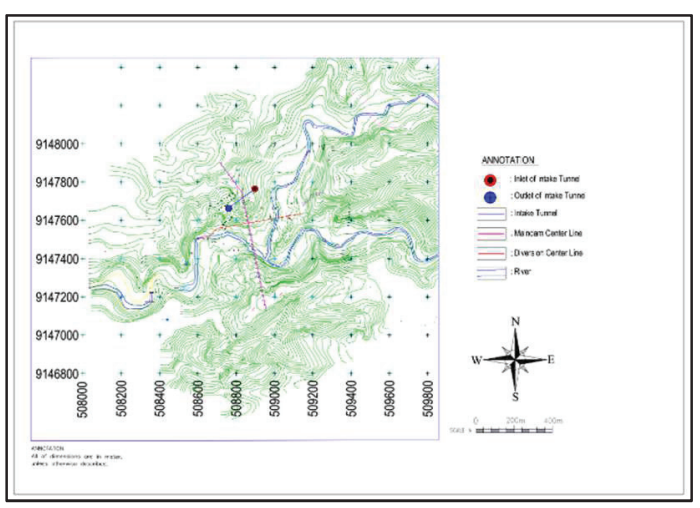

Fig 1. Location of Jlantah dam intake tunnel

Several site investigations have been carried out in the design stage of the dam construction. Still, the study of rock mass characterization in the intake tunnel was not carried out in detail. Details of the intake tunnel design have been made, however, the empirical determination of the tunnel excavation method and the support system has not been carried out [6]. It is necessary to select a safe and stable excavation method and tunnel support system based on the classification of rock mass quality. Several analytical methods can be performed to identify the rock mass characteristics of a tunnel. The determination of rock mass classification empirically used in this study uses the RMR system [3] and the Q-System [1].

\section{Geological Conditions}

Based on the Geological Map of the Ponorogo Sheet compiled by Samodra \& Sampurno [7], the rock formations at the tunnel location and its surroundings consist of Lava Lawu (Ella) Jobolarang Lava (Qvjl), and Lava Sidoramping (Qvsl) formations. Observations of rock outcrops indicate that the research area consists of 4 rock units from old to young, namely: Volcanic Breccia Unit, Slightly and Moderately weathered Lapilli Tuff Unit, and Silt Sand Soil Unit. The map of the distribution of rock units and the geological cross-section of the research location can be seen in Figures 2 and 3. The rock units in the research area are included in the Lawu Volcano sediment with a Holocene age. The path of the intake tunnel is located in the Tuff Lapilli Unit. The rock mass classification in the study area has rock discontinuity with high to slightly weathering rates. 


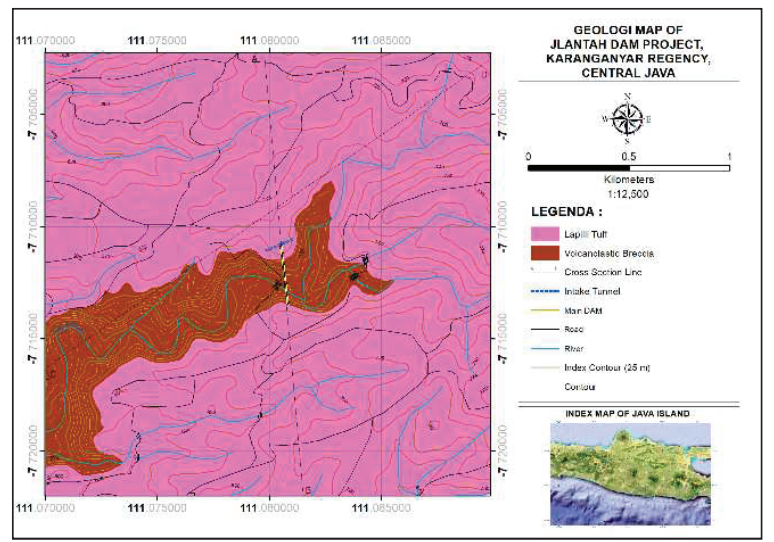

Fig. 2 Geological map of the research area

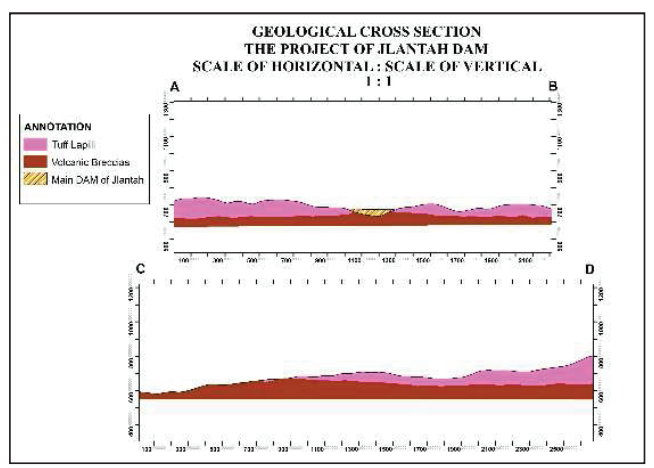

Fig. 3. Geological cross section of Jlantah dam

The Jlantah Dam intake channel has a total design length of 185 meters. The intake channel is a combination of a 172-meter long tunnel and a 13-meter long conduit with dimensions of $4.2 \mathrm{~m}$ [6].

\section{Methodology}

The main reason for using RMR is its ease and flexibility in various practical purposes in engineering (Bieniawski, 1989). According to Bieniawski (1989), the rock mass classification of the RMR method uses 6 (six) parameters with measurements that can be carried out in the field and interpretation of drill hole data. These parameters include 1) Uniaxial Compressive Strength (UCS) of intact rock material, 2) Rock Quality Designation (RQD), 3) discontinuity spacing, 4) discontinuity conditions, 5) groundwater conditions, and 6) discontinuity orientation. The rock mass quality parameters are used to determine the RMR value at the research site based on Bieniawski, (1989) [3]. In addition, Bieniawski also determined the support system in the form of type, diameter, and length of rock bolt, steel set, and shotcrete based on the RMR value as described in Bieniawski [2].

The initial Q-System, is a system that takes into account six parameters: RQD, amount of fracture, the roughness of the fracture, change in stock, water conditions on the stock, and the pressure factor [1]. The basic geotechnical parameters according to Barton [1] are block size, minimum shear strength between blocks, and active pressure. The basic geotechnical parameters are represented by the following ratios [5]: 1) Relative block size $=\mathrm{RQD} / \mathrm{Jn}, 2$ ) Relative strength of friction $=\mathrm{Jr} / \mathrm{Ja}$, and 3) Active pressure $=\mathrm{Jw} / \mathrm{SRF}$. The determination of rock mass quality is obtained from the following equation [1]:

$$
\mathrm{Q}=\frac{R Q D}{J n} \times \frac{J r}{J a} \times \frac{J w}{S R F}
$$

Description: RQD $=>10 ; \mathrm{Jn}=$ number of stockings; Jr = roughness value; $\mathrm{Ja}=$ value of change in stock; Jw = water value and reduction factor; $\mathrm{SRF}=$ reduction of stress factors in fracture, strength / stress ratio in hard boulders and swelling / squizing rocks.

The range of Q values varies between 0.001 and 1000 . The correlation of the Tunneling Quality Index (Q) with the behavior and support requirements of underground excavation called Equivalent Dimensions (De) is defined as follows:

$$
\text { De }=\frac{\text { Height of tunnel }}{\text { Excavation Support Ratio }}
$$

The ESR value for the water tunnel is 1.6 as recommended by Barton [1].

\section{Results and Discussion}

The morphology in the study area is mainly influenced by the volcanic activity of the old and young Lawu Mountains, with the characterization of steep to very steep slopes. The lowest elevation is the slat where the Jlantah River passes. From the results of the surface geological mapping that has been carried out along the Jlantah River and the Puru River, starting from the plan of the Jlantah Dam to the inundation plan area, it is known that the regional geological structure pattern covering the investigation area has a west-east straight line and is not a fault. The local geological structures found are the stocky structure of the breccias and poor bedding on the breccias sandstone insert.

Rock Mass Rating is obtained from the sum of all the rock mass parameter weights obtained from the research location. The RMR value obtained from the rock test results, field observations then carried out the rock mass classification. RMR and Q-system data were taken from face mapping of tunnel excavations at 6 locations and from observations of core drill results as much as 2 points, namely BS7 and BS11. Face mapping is carried out after the excavation is complete and before the support system is installed. Observation of core drill results is carried out by directly assessing core drilled rock and comparing it with the photo documentation at the beginning and supported by laboratory testing to obtain index and mechanical properties.

Based on observations on the results of the core drill (figure $6 \& 7$ ) and the face of the tunnel (figure $4 \& 5$ ), the 
RMR value of the tunnel varies between 18 - 35 so that it can be classified into 3 rock mass classes, namely 1) lapilli tuff with very poor quality (RMR value $18-20)$, 2) poor quality lapilli tuff (RMR 21 - 27) and 3) medium quality lapilli tuff (RMR 28 - 35).

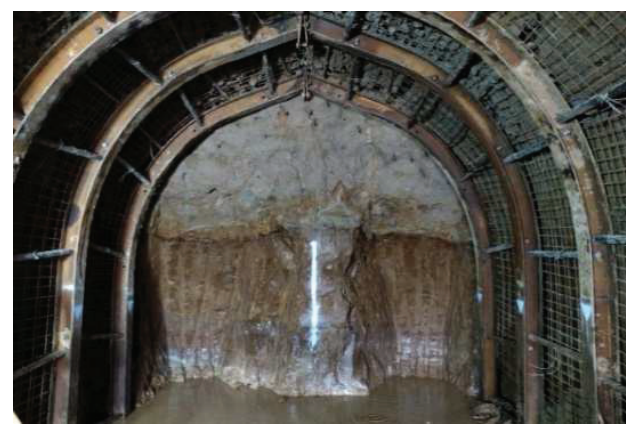

Fig. 4. Appearance of lapilli tuff on the inlet tunnel face

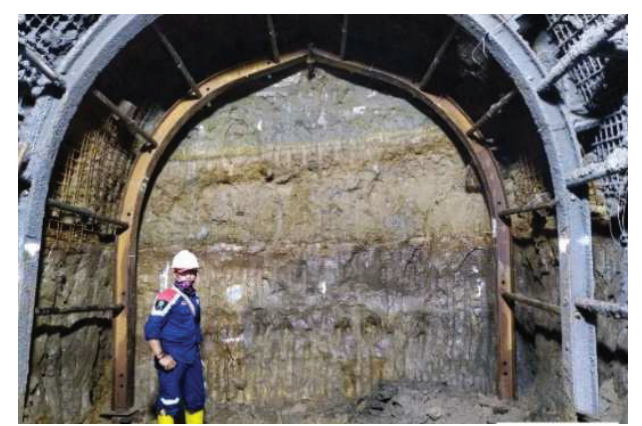

Fig. 5. Appearance of lapilli tuff on the outlet tunnel face

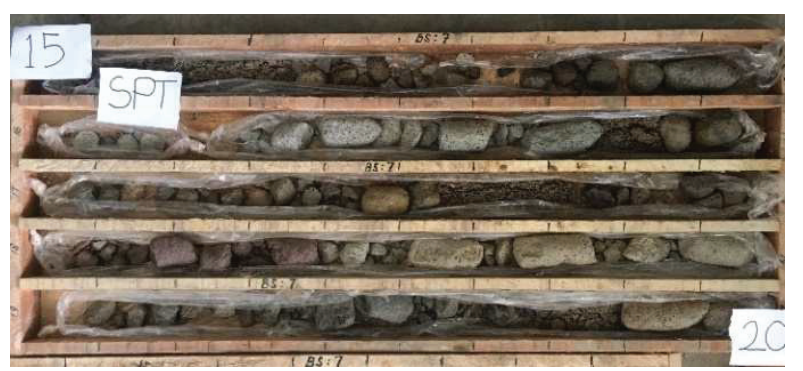

Fig. 6. Typical drill cores at the research location, material lapilli tuff poor quality

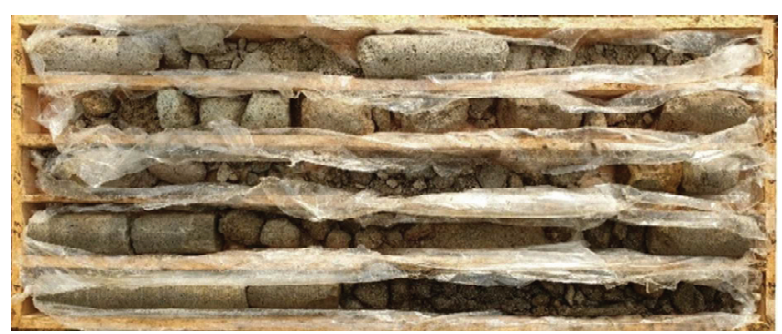

Fig. 7. Typical drill cores at the research location, material lapilli tuff with medium quality

The tunnel support system recommendation can determine how long a tunnel is safe without a support system. Based on the RMR value and recommendations from Bieniawski [2], the recommended method of excavation is top heading and bench. The recommended support system is a steel set with a distance of $1.5 \mathrm{~m}$, shotcrete with a thickness of $10-15 \mathrm{~cm}$, and a rock bolt with a length of $4-5 \mathrm{~m}$ with a distance of $1-1.5 \mathrm{~m}$.

The tunnel stability analysis criteria can be expressed in the form of a graph of the relationship between the RMR and the unsupported span to determine the stand-up time value (Figure 8). The recommended standup time value for tunnels with very poor quality lapilli tuff rock mass class is $0.8 \mathrm{~m}$ long without reinforcement for 1 hour. The standup time value for the poor quality lapilli tuff rock mass class is $1 \mathrm{~m}$ long without reinforcement for 1.5 hours. The standup time value for the poor quality lapilli tuff rock mass class is $1.5 \mathrm{~m}$ without reinforcement for 3 hours.

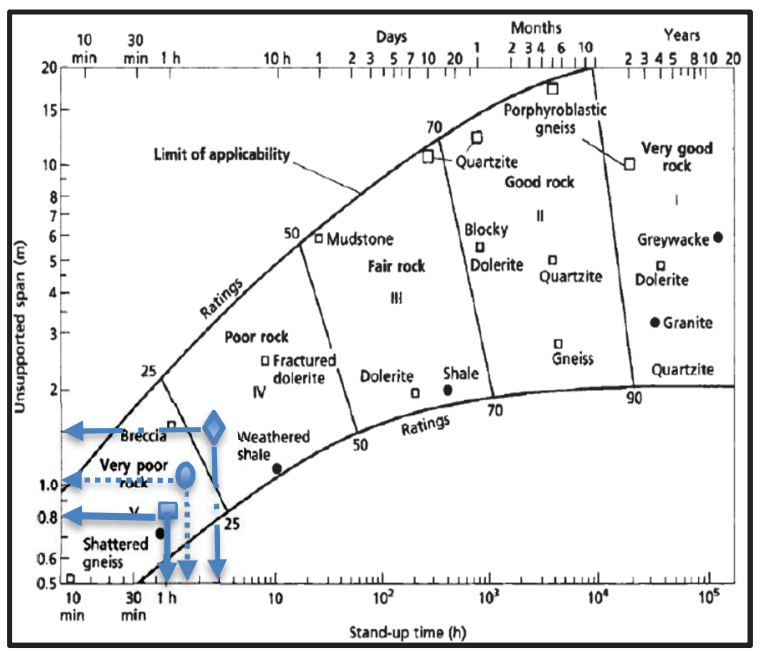

Fig. 8. The relationship between stand-up time and unsupported span for rock mass classes [3]

The Q-system value is obtained from the sum of all rock mass parameter weights obtained from the research location. The Q-system value obtained from the rock test results, field observations then carried out the rock mass classification.

Based on observations on the results of the core drill and the face of the tunnel excavation, the Q-system value of the tunnel varies between $0.23-0.58$ so that it can be classified into 3 rock mass classes, namely 1) lapilli tuff with very poor quality ( $Q$ value $0.23-0.35), 2$ ) poor quality lapilli tuff (Q value 0.36 - 48) and 3) medium quality lapilli tuff ( $Q$ value 0.49 - 58).

The tunnel diameter is $4.2 \mathrm{~m}$ and the ESR value is 1.6 so that the Equivalent Dimension (De) value is 2.6. The $\mathrm{Q}$ value and De value will be input on the Q-system graph to get a buffer system recommendation based on the Qsystem (Figure 9). The support system for very poor quality lapilli tuff is fiber-reinforced shotcrete $5-9 \mathrm{~cm}$ thick and rock bolt $1.6 \mathrm{~m}$ long with a distance of $1.4 \mathrm{~m}$. The support system for poor quality lapilli tuff is fiberreinforced shotcrete $5-9 \mathrm{~cm}$ thick and $1.6 \mathrm{~m}$ long rock bolt with a distance of $1.5 \mathrm{~m}$. The support system for medium quality lapilli tuff is fiber-reinforced shotcrete 5 - 
$9 \mathrm{~cm}$ thick and $1.6 \mathrm{~m}$ long rock bolt with a distance of $1.6 \mathrm{~m}$.

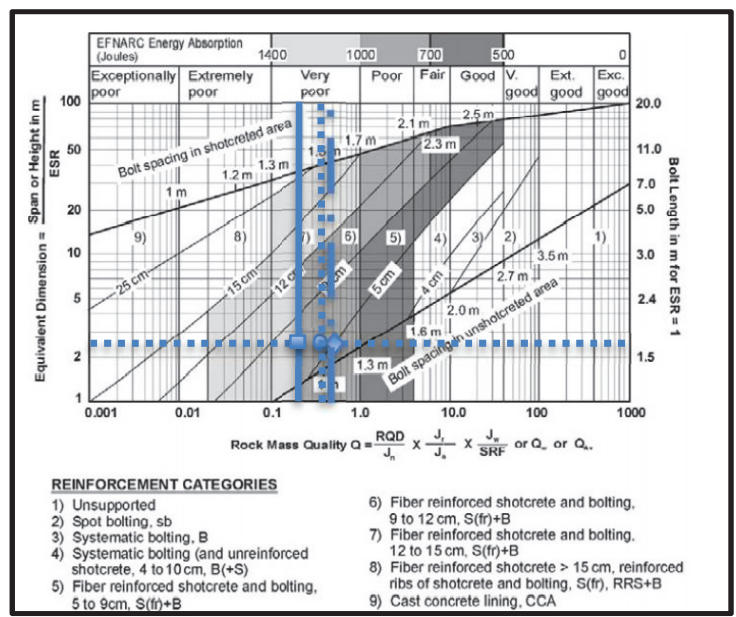

Fig. 9. The Q support chart [5]

Technical geological parameters such as discontinuity conditions, water conditions and the RQD value of a rock will determine the value of rock mass class so that the geological condition of a rock will determine the appropriate excavation method and support system for the rock. For example, geological processes affect the occurrence of rock discontinuity areas, causing the level of rock weathering and rock joint conditions. Another example is the direction and angle of rock layers (dipping) based on RMR which affects the value of rock mass quality. In the case of the tunnel intake, the Jlantah Dam has a rock mass quality value of poor to very poor, so the recommendation for the excavation method used is top heading and bench.

\section{Conclusions and Recommendations}

Based on the RMR method, the rock mass at the research location is in class IV (poor rock) and class V (very poor rock) with an RMR value ranging from 18 - 35. Based on the Q-system method, it is obtained rock mass with very poor rock class and value The Q-system ranges from 0.23 -0.58 .

Based on the classification of the RMR value, the recommended method of excavation is top heading and bench. The recommended support system is a steel set with a distance of $1.5 \mathrm{~m}$, shotcrete with a thickness of 10 $-15 \mathrm{~cm}$, and a rock bolt with a length of $4-5 \mathrm{~m}$ with a distance of $1-1.5 \mathrm{~m}$. The standup time value is $0.8-1.5$ $\mathrm{m}$ without reinforcement for $1-3$ hours. The recommendation for the support system according to the Q-System is fiber-reinforced shotcrete $5-9 \mathrm{~cm}$ thick and $1.6 \mathrm{~m}$ long rock bolt with a distance of $1.4-1.6 \mathrm{~m}$.
Based on the analysis of the RMR and Q-system methods, the suitable support system for engineering geological conditions such as the intake tunnel of the Jlantah Dam is shotcrete $10 \mathrm{~cm}$ thick, steel set with a distance of $1.5 \mathrm{~m}$ and rockbolt length of $1.6 \mathrm{~m}$ with a distance of $1.5 \mathrm{~m}$. The proper excavation method for the tunnel intake of the Jlantah Dam is top heading and bench. In practice, it is suggested to use these two systems according to needs, sometimes one another complements or corrects each other to get the right decision.

Thank you very much to BBWS Bengawan Solo for research and Mr. I Gde Budi as the supervising lecturers of Masters in Geological Engineering, Gadjah Mada University, so that this journal can be completed. We acknowledge PT. Waskita Karya (Persero) for the financial support for education and research through the super-specialist program held by PUPR in the year 2020.

\section{References}

1. N.R Barton, R. Lien, J. Lunde, Engineering classification of rock a masses for the design of tunnel support, New York. (1974)

2. Z.T. Bieniawski, Rock mechanics design in mining and tunneling (p. 272). Rotterdam (1984).

3. Z.T. Bieniawski, Engineering Rock Mass Classification, NewYork: John Wiley \& Sons (1989)

4. D.U. Deere and D.W. Deere, $R Q D$ Index, U.S. Corps of Engineers, Washington DC (1967)

5. E. Grimstad and N. Barton, Updating of the $Q$ system for NMT, in Proceedings of the International Symposium on Sprayed Concrete- Modern Use of Wet Mix Sprayed Concrete for Underground Support, Fagernes: Oslo, page. 46-66 (1993)

6. PT. Aditya, Studi Investigasi Tambahan Untuk DD Waduk Jlantah, Kartasura (2017)

7. Sampurno and H. Samodra, Peta Geologi Lembar Ponorogo, Bandung (1997) 